\title{
Driving factors of sustainable production in upland watersheds: systematic literature review
}

\author{
Fitriani Fitriani $^{1 *}$, and Didik Kuswadi ${ }^{2}$ \\ ${ }^{1}$ Agribusiness, Economics and Business Department, Politeknik Negeri Lampung, 35145 Rajabasa \\ Bandar Lampung, Lampung, Indonesia \\ ${ }^{2}$ Land and Soil Engineering, Agricultural Technology Department, Politeknik Negeri Lampung, \\ 35145 Rajabasa Bandar Lampung, Lampung, Indonesia
}

\begin{abstract}
Sustainable production in upland watersheds is a formidable challenge for farmers. The trade-off laid between economic benefits (productivity) and sustainability. Farmers' resilience in the upstream watershed needs to meet sustainable agricultural production. This paper was conducted to review the local driving factors which are supporting economic resilience and climate change mitigation to sustainable production in upland watersheds. Systematic Literature Review (SLR) design as preliminary exposure toward the key variables and driving question. The framework of a systematic literature review refers to the conservation and environmental management that is built with PRISMA protocol. SLR protocol starts from planning review, citation screening, data extraction, and analysis. The review addressed terms of current developments and plans for the participatory in sustainable watersheds management. This review article performed the basic steps of SLR and meta-analysis studies on environmental science and agricultural and biological science fields. The SLR protocol starts from planning review, citation screening, data extraction, review progress, the analysis result. The keywords addressed to current study in sustainable production in upland watersheds. This review has highlighted that agroforestry as a primary driving factor in directing the sustainable production in upland. Agroforestry within coffee farming could set as sustainable production system in upstream watersheds.
\end{abstract}

Keywords: sustainable, coffee, upland, farming, agroforestry

\section{Introduction}

Agricultural production in upland massively for cash crop farming run for a long century ago. A variety of cash crops, especially horticulture, plantations, and food crops cultivated especially surrounding the watersheds area. Farming in upland and watersheds tends to be assumed as the cause of land degradation, erosion, and landslides. Based on the Ministry of Agriculture Decree No. 47/Permentan/OT.140/10/2006 the general guidelines for agricultural cultivation in upland (mountain land) were issued due to implement good agricultural principles/practices (GAP) to provide the maximum economic and environmental benefits for the wider community. The proper cultivation management in the upland area with conservation application has a positive impact on the sustainability of

\footnotetext{
* Corresponding author: ftriani@polinela.ac.id
} 
land resources and the environment, especially in the availability of water stock in the downstream area. The implementation of GAP in upland areas plays an important role in many aspects of life, especially in sharpening the sustainable development goals (SDGs). SDGs crystalised the three comprehensively: the economy is part of the social, and the social part of the environment. Promoting sustainable agriculture, as economic activity forms are subject to social interests and environmental sustainability. Furthermore, it will empower the community's economy, employment expansion, environmental conservation (better hydrological cycles and biodiversity), amenity, and regulation of important parts of life.

How the farmer maintains sustainable production in upland watersheds is challenging. The farmer faces the trade-off between economic benefits (productivity) and sustainability of the carrying capacity of the environment, including the problem of climate change that causes the risk of farming failure. Farmers' resilience and risk mitigation capabilities on climate-changing in upland are necessary to meet sustainable agricultural production. Promoting sustainable agriculture, as economic activity forms are subject to social interests and environmental sustainability.

Smallholders' coffee farming mostly spread in upland watersheds. Coffee is an important commodity that trades broadly around the world. It involved more than 2 million households that depend on coffee chain business in Indonesia. Indonesia is the $4^{\text {th }}$ largest coffee exporter in the global market. The trend of requirements for environmentally sustainable coffee has now become the demand of the global market. Nowadays, agricultural products are no longer only assessed because of the quality of their products but also on how the basis of the coffee production on sustainable cultivation circumstances run. It linked on GAP implementation, shade tree planting, conservation technic, control of plant pests, and preservation of natural resources including biodiversity. Coffee certification is one of the global buyer's requirements for sustainable production in the last decade. Therefore, the coffee business chain needs aware of fulfilling the various requirements that must be met to the environmentally friendly.

Establish sustainable agricultural practices influenced by socioeconomic characteristics and information-seeking behaviors [1]. The risk-taking on coffee farming is associated with the conditions of ownership status, production decline, and environmental conditions. Social actors will strongly influence decisions and choices of sustainable farming practices $[2,3]$. Social and economic factors of communities around forest areas play a very important role in the type of commodity pattern choice [4]. Farmers' resilience and risk mitigation capabilities on upland watersheds are essential to meet sustainable agricultural production. This paper aimed to review the local drivers which are supporting economic resilience and climate change mitigation to sustainable production in upland watersheds.

Sustainable coffee development in Indonesia faces multi-dimensional challenges lied from climate changes, dynamic global economic disruption that impacted the world coffee prices [5], high-quality coffee requirement, certification issues, farmer institutions, until the increasing demand because of increasing population and changes in the lifestyle of coffee consumption [6-9]. Building environmentally friendly for coffee production it is necessary to hand by hand with the right policies, research, capacity building as well as guidance and counseling for coffee farmers to enhance their prosperity.

The treasury study of the evidence of sustainable coffee production in upland watersheds is a part of the sustainable production achievement agenda in SDGs target. The systematic literature review (SLR) is needed as the first step to exposure the position of the study evidence, trace the novelty possibilities, and the direction of the research in the future $[10,11]$. The information will be set as a database in the next empirical study. It is a part of scientific evidence and necessary information transfer based on theory to a practical level and empirical studies. Understanding how the farming stakeholders in upland concern and 
participatory involved toward sustainable production establishment is very strategic. The awareness will motivate to take real action for the proper management solutions and help the development or improvement of the specific problem. This paper focused on digging the literature review on the term, authorship, novelty, research necessity direction related to the establishment of local drivers in supporting the sustainable coffee production in upland watersheds.

\section{Materials and methods}

SLR designed as preliminary exposure toward the key variables and driving question. A SLR refers to the conservation and environmental management that is built from an environmental model with PRISMA protocol [12,13]. A protocol is a document that presents an explicit plan for a systematic review. It steps up from planning, screening, extraction, and analysis. The review addressed terms of current developments and future plan for the participatory in sustainable upland watersheds management, especially in coffee farming. SLR conducted as a Web-based open-access library by case studies. The data generated based on the primary sources from Google Scholar, Nature, Web of Science, Elsivier-Scopus, and Dimension. The paper selection review based on the tittle, abstract, and keywords.

SLR set the checklist to help report all types of systematic reviews (Beller et al. 2013) as follows. SLR analysis conducted with Colander application (https://www.colandrapp.com/ ) that is a web-based open access platform for conduct a review of the evidences [10]. This web-based application perfored text mining and analysis which supports scholarly reading and interpretation of texts from the selected articles. The tool also could assess the frequencies of keywords from all selected published articles. Then the mapping analysis applied the VosViewer tool [14].

Table 1. The SLR checklist as protocol preparation

\begin{tabular}{|c|c|}
\hline 1. Tittle & Coffee sustainable production in upland watersheds \\
\hline $\begin{array}{l}\text { 2. Background } \\
\text { (objectives) }\end{array}$ & $\begin{array}{l}\text { Determine the drivers' factor in establishing the coffee sustainable } \\
\text { production in upland watersheds }\end{array}$ \\
\hline 3. Methods & Empirical study \\
\hline a. Eligibility criteria & $\begin{array}{l}\text { PICO } \\
\text { Population : ecosystem, upland, watersheds, farmers, stakeholders that } \\
\text { should be defined in terms of the subject (s) whom the intervention will } \\
\text { be applied on upland watersheds management } \\
\text { Interventions : } \\
\text { proposed management regime, policy, program, action, mitigation, or } \\
\text { local wisdom, good agriculture practice, agroforestry } \\
\text { Comparison } \\
\text { The intervention being compared with no intervention or are alternative } \\
\text { interventions being compared with each other } \\
\text { Outcomes } \\
\text { All relevant objectives of the proposed management intervention that can } \\
\text { be measured benefits or disadvantages than any other alternatives (the } \\
\text { outcome desired income, welfare, livelihood, resilience) }\end{array}$ \\
\hline b. Informati & Google Scholar; Dimension; Nature ; Elsevier Scopus \\
\hline 4. Results & \\
\hline $\begin{array}{l}\text { a. Included study } \\
\text { (question drivers) }\end{array}$ & $\begin{array}{l}\text { What kind of risk that face by farmers in upland watersheds area? } \\
\text { Who will consider managing and mitigating risk in the upland } \\
\text { watershed? } \\
\text { How the farmer's concern in mitigating the risk? } \\
\text { What kind of farmers adapt in facing the ecological risk in their upland }\end{array}$ \\
\hline
\end{tabular}




\begin{tabular}{|l|l|}
\hline & $\begin{array}{l}\text { cultivation ? } \\
\text { When the farmers take an action to mitigating the ecological risk in their } \\
\text { land and agriculture production ? } \\
\text { How do the farmers managing the good agricultural practices system in } \\
\text { their land }\end{array}$ \\
\hline $\begin{array}{l}\text { b. Synthesis of result } \\
\text { and the effect } \\
\text { description }\end{array}$ & $\begin{array}{l}\text { All relevant objectives of the proposed management intervention that can } \\
\text { be measured benefits or disadvantages than any other alternatives (the } \\
\text { outcome desired income, welfare, livelihood, resilience) }\end{array}$ \\
\hline 5. Discussion & \\
\hline $\begin{array}{l}\text { a. Strength dan } \\
\text { limitation of evidence }\end{array}$ & Time duration ; open access article journal sources, DOAJ \\
\hline b. Interpretation & Authorship; key word, citation \\
\hline
\end{tabular}

Table 2. The selection area and label information

\begin{tabular}{|l|l|}
\hline \multicolumn{1}{|c|}{ Selection Criteria } & \multicolumn{1}{c|}{ Label } \\
\hline Population & $\begin{array}{l}\text { Global agricultural cash crop stakeholder (consumer, trader, producer, } \\
\text { smallholder, institution) }\end{array}$ \\
\hline Cash crop trade driver & Market, endowment, institution, trade network \\
\hline economic impact & Economic growth, income, job creation, poverty, vulnerability \\
\hline environmental impact & Food security, sustainability \\
\hline Intervention & $\begin{array}{l}\text { Trade policy, government regulation, socio-economic, sustainability } \\
\text { concern }\end{array}$ \\
\hline Duplicate & Duplicate paper \\
\hline Time frame & The last 15 years \\
\hline Study design & Relation between trade drivers and trade outcomes \\
\hline Topic & Relevant to trade \\
\hline Others & Not accessible or not found \\
\hline
\end{tabular}

Table 3. The term, synonym, and group information

\begin{tabular}{|l|l|l|}
\hline \multicolumn{1}{|c|}{ Term } & \multicolumn{1}{|c|}{ Synonym } & \multicolumn{1}{c|}{ Group } \\
\hline Risk & Negative impact, excess, disaster, loss & Ecological risk \\
\hline Resilience & Survival, defense, restrain, retain, endurance & Resiliency \\
\hline Livelihood & Adaptation, prevention, recognition, admission & Mitigation \\
\hline Farming & $\begin{array}{l}\text { Food security, welfare, adequate income, } \\
\text { wellbeing }\end{array}$ & welfare \\
\hline Cash crop & $\begin{array}{l}\text { Cultivation, agricultural practices, production } \\
\text { system }\end{array}$ & $\begin{array}{l}\text { Agriculture } \\
\text { production }\end{array}$ \\
\hline Farmer's institution & $\begin{array}{l}\text { Coffee, cocoa, palm oil, rubber, pepper, paddy, } \\
\text { cassava, corn }\end{array}$ & $\begin{array}{l}\text { Farmers' group, farmers' association group, } \\
\text { forest community management, cooperative }\end{array}$ \\
\hline $\begin{array}{l}\text { Climate change } \\
\text { impact }\end{array}$ & $\begin{array}{l}\text { Erosion, sedimentation, land degradation, } \\
\text { deforestation, flood, drought }\end{array}$ & Local institution \\
\hline
\end{tabular}

\section{Results and discussion}

\subsection{Building PRISMA protocol of SLR}

Exposure the body of knowledge of coffee sustainable production is linked to the evidence of the drivers of good agricultural principle (GAP) in upland farming. Contrary, the most theme in upland management research focus on agricultural expansion and the land use change. Then understanding the current situation of sustainable production drivers is more 
important for future sustainable agriculture development that prevent the environmental carrying capacity. The tracing of the existing literature on trend, drivers, and restriction of sustainable production in upland will inform the scientific evidence for the next empirical study.

Literature review developed by the set question, it related with the kind of risk in upland watersheds, managing and mitigating risk action, the cultivation risk adaptation, and managing the good agricultural practices system in farm land. The determination of the relevant articles returned from the search strings as follows. Abstract articles and tittles screened according to inclusion criteria of practices, interventions, and outcomes. Then, the full text that met with initial inclusion on the abstract will be downloaded and screened by the same eligible criteria. The terms used in the search engines are set as the Boolean search query as follows.

\section{Boolean Search Query}

("risk" OR "negative impact" OR "excess" OR "disaster" OR "loss") AND ("resilience" OR "survival" OR "defense" OR "restrain" OR "retain" OR "endurance") AND ("Mitigation" OR "adaptation" OR "prevention" OR "recognition" OR "admission") AND ("Livelihood" OR "food security" OR "welfare" OR "adequate income" OR "wellbeing") AND ("Farming" OR "cultivation" OR "agricultural practices" OR "production system") AND ("cash crop" OR "coffee" OR "cocoa" OR "palm oil" OR "rubber" OR "pepper" OR "paddy" OR "cassava" OR "corn") AND ("Farmers' institution" OR "farmers' group" OR "farmers' association group" OR "forest community management" OR "cooperative") AND ("Climate change impact" OR "erosion" OR "sedimentation" OR "land degradation" OR "deforestation" OR "flood" OR "drought").

\section{Extraction and analysis}

Data extraction runs after the screening process. After the full-text screening and extraction then the result was restored in the export icon. Extraction and analysis process applied the ColandrApp. Based on [10] the strict inclusion and exclusion criteria was needed to narrow down the results for the most relevant papers in the review work [11]. Selection articles were evaluated based on the review work objective. The screening of the selection literature identify the relevant papers for the review work trough the basic steps: selection studies using inclusion criteria and quality assessment. The inclusion and exclusion criteria use in selection of related studies, papers that fulfill the inclusion criteria were selected for further investigation and content assessments. Table 4 performed the predefined literature inclusion and exclusion criteria to achieve SLR work. Reduction paper focus on papers labels, such as gray literature type, extended abstracts, presentations, keynotes, and review articles.

The flow of selection relevant literature and the general paper screening process were presented in Fig.1. First, for the initial stage, a sum of paper counted of 1.453 were found (Table 4). Then the literature that marked as gray literature, extended abstracts, presentations, keynotes, book chapters, and inaccessible publications removed. 
Table 4. The result of analysis data extraction

\begin{tabular}{|l|r|}
\hline Total studies1453 & 1.453 \\
\hline Database1453 & 1.453 \\
\hline Unique studies1453 & 1.453 \\
\hline Screened citations447 & 474 \\
\hline Excluded citations143 & 143 \\
\hline Screened fulltexts304 & 340 \\
\hline Excluded fulltexts132 & 132 \\
\hline Studies with data extracted172 & 172 \\
\hline Exclusions by reason & 54 \\
\hline Intervention54 & 23 \\
\hline Topic23 & 20 \\
\hline Environmental impact20 & 7 \\
\hline Cash crop trade driver7 & 13 \\
\hline Economic impact13 & 6 \\
\hline Population6 & 1 \\
\hline Duplicate1 & 18 \\
\hline Study design18 & 2 \\
\hline Others2 & \\
\hline
\end{tabular}

Assessment the quality of SLR adjusted to clarify that the paper selection relevant and still update with the recent study. SLR evaluated by the criteria of quality assessment questions [10]:

Q1. Are the review's criteria of inclusion and exclusion described and appropriate?

Q2. Is the literature search covered all relevant studies on the topic?

Q3. Was the type of keywords mentioned in the publication described adequately?

Both of extraction and classification step of the synthesis conducted to relevant data from selected papers that derived knowledge and conclusions. The process of data extraction involved the identification and extraction of relevant data from the selected papers. Paper removing amount 1.006, then the number of paper that retained for further title reading reach to 447 articles. Excluded citations counted to 143 paper, then screened full-texts run to 304 papers. The next step was screening for excluded full-texts 132 papers. Then only 172 articles fulfilled the eligibility criteria for further abstract reading. In the last, only 40 articles were remained for the main body reading. Exclusions paper by reason counted by intervention (54), topic (23), impact (20), studi design (18), and economic (13). Finally, 40 publications that fulfilled all the inclusion criteria used in this SLR work (see Fig. 1). The final list of related publications was downloaded for further analysis. The result of analysis data extraction will display with the PRISMA flow diagram as follows. 




Fig. 1. Data extraction on PRISMA flow diagramme

\subsection{Driving factor of sustainable production in upland}

VosViewer addresses to map the SLR objectives, the termes organisation on the general characteristics and on the specific parameters. It includes the spesific key words, authors, organization, citatiton, year scope, the numbers of document citated. The article genarated as the interest theme and group as coffee agroforestry, sustainability, and institution governacy which were defined and indicated in Table 5. Finally, the data related to each selected paper was extracted, then the mapping of the trends on the term and author described by Vosviewer app as follows to prepare it for further analysis.

Personal judgements of the analyst, researchers and understanding level of the research and study purpose influences analysis and result reporting process. An application of statistical analysis tools in SRL and meta-analysis depends on the nature of the studies. It is important and necessary to convey results in reasonable way and also to convince final output users [15]. 
\& vosviewer



Fig. 2. The density of term cluster on sustainable drivers' production

There were three main cluster terms that lead as the largest bullet, i.e agro-forestry, theory of eco-services, and payment environmental services. Agroforestry and payment services displaid in Figure 3.

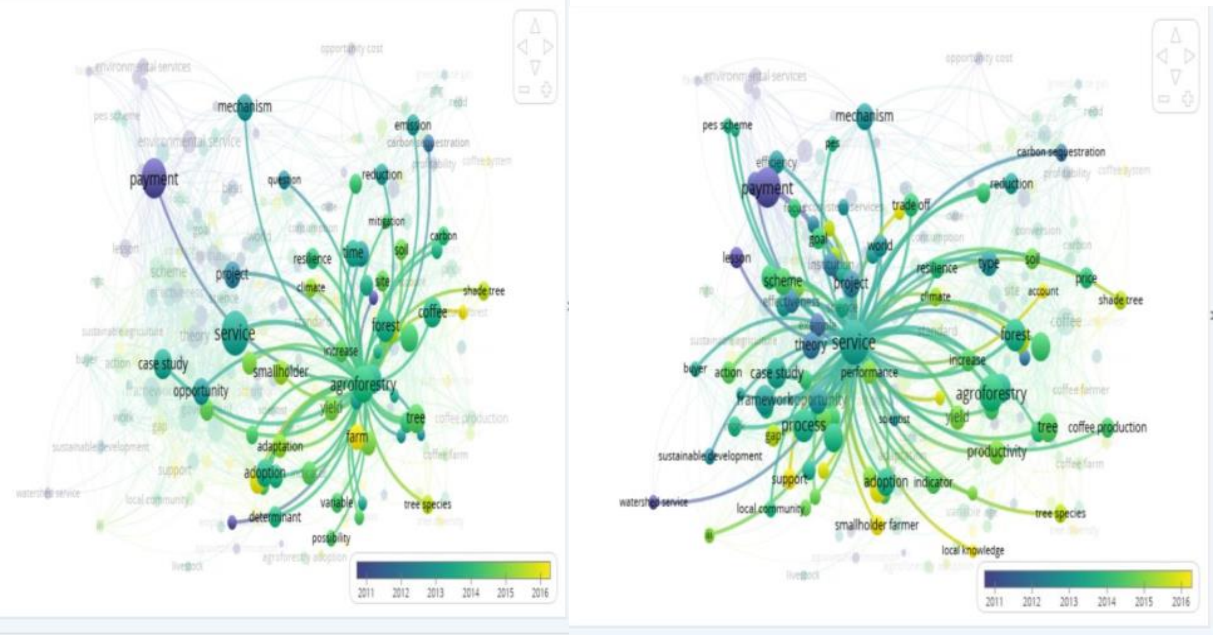

Fig. 3. The main cluster term as sustainable drivers' production

The tracing of the "coffee" and it-term connection toward sustainable production display as follows. The analysis phase encompassed the evaluation of synthesized data and the extraction of meaningful information and concluding the selected papers. At this phase, the formulated research questions would have answers. It covers both the qualitative and quantitative explanation and narration of the results, making discussion, indicating the way forward about the future research works and inferring a conclusion. The data from the final list of selected articles can be summarized in descriptive and/or basic inferential statistical techniques. The type and use of statistical tools depend on "the nature of the research findings, the type of statistics reported for each study, and the hypotheses tested by the meta-analysis" [21]. 




Fig. 4. Coffee term connection toward sustainable production

The last selection paper step was the final report phase of SLR. The paper concern related to the puposes, the methods, and the results as conclusion. A journal article production in SLR procedure was helps to provide the research output for scientific purposes. Based on the PRISMA flow diagram and selection process step there were 40 papers as new studies as follows. Then research finding on sustainable production theme based the authorship displaid in Table 6 .

Table 5. Sustainable coffee production theme based the authorship

\begin{tabular}{|l|l|l|}
\hline Coffee agroforestry & Sustainable agroforestry & Institution governancy \\
\hline (Luo et al., 2015) [16] & (Coe et al., 2014) [17] & (Valencia, et.al., 2015) [18] \\
\hline Binam, et.al., (2015) [19] & (Dawson et al. 2013) [20] & (Maryanto, dkk., 2014) [21] \\
\hline (Lasco, et.al., 2013) [22] & (Kittur and Bargali, 2014) [23] & Fauzi Hamdani, 2014 [24] \\
\hline (Minang, et.al., 2014) [25] & (Reisland 2013)[26] & Purwanto, 2018 [27] \\
\hline (Mbow et al. 2014) [28] & (Syaukat, 2011) [29] & Lastiantoro (2014) [30] \\
\hline (Luedeling et al. 2014)[31] & (Jaji 2011) [32] & (Ruhimat, 2015) [33] \\
\hline (Kiptot et al., 2014) [34] & & Fauziyah, dkk., (2013) [35] \\
\hline (Luiz et al., 2014) [36] & (Barios et.al., 2018) [37] & $\begin{array}{l}\text { (Takahashi and Todo 2012) } \\
\text { [38] }\end{array}$ \\
\hline (Rosin et al., 2014) [39] & (Assogbadjo et al. 2012) [40] & (Chen et al. 2012) [41] \\
\hline (Coe et al., 2014) [17] & (Magcale-Macandog, et.al., & (Hidayat, 2010) [43] \\
\hline $\begin{array}{l}\text { (Jerneck and Olsson 2013) } \\
\text { [44] }\end{array}$ & (Okubo and Koji 2010) [45] & (Santoso 2010) [46] \\
\hline (Pender et a., 2008) [47] & (Asah, 2008) [48] & (Tole and Á 2010) [49] \\
\hline
\end{tabular}


Table 6. Research finding on sustainable production theme based the authorship

\begin{tabular}{|c|c|}
\hline Author & Result Finding \\
\hline $\begin{array}{l}\text { Binam, et.al., } \\
(2015)[19]\end{array}$ & $\begin{array}{l}\text { Agroforestry maintaining, protecting and managing trees on agricultural land } \\
\text { has a significant influence on the well-being of the rural poor }\end{array}$ \\
\hline $\begin{array}{l}\text { (Luo et al., } \\
2015)[16]\end{array}$ & $\begin{array}{l}\text { creased cover crops reduced surface run-off and sediment yields. Soil organic } \\
\text { atter and cover crops correlated to soil quality degradation. }\end{array}$ \\
\hline $\begin{array}{l}\text { (Lasco, et.a } \\
2013)[22]\end{array}$ & $\begin{array}{l}\text { Agroforestry on livestock can be scaled up in several ways through optimizing } \\
\text { agroforestry dynamics that are compatible with local practices, cultural norms } \\
\text { and traditions. }\end{array}$ \\
\hline $\begin{array}{l}\text { (Minang, } \\
\text { et.al., 2014) } \\
\text { [25] }\end{array}$ & $\begin{array}{l}\text { More than half of REDD }+ \text { strategies in African countries identify agroforestry } \\
\text { as a strategic option for the effective, efficient and equitable delivery of } \\
\text { REDD+. }\end{array}$ \\
\hline $\begin{array}{l}\text { (Mbow et al. } \\
\text { 2014) [28] }\end{array}$ & $\begin{array}{l}\text { The agroforestry system becomes a bundle of mitigation and adaptation } \\
\text { strategies that can secure food security for poor farmers, and contribute to } \\
\text { climate change mitigation. }\end{array}$ \\
\hline $\begin{array}{l}\text { (Luedeling et } \\
\text { al. 2014)[31] }\end{array}$ & $\begin{array}{l}\text { y systems practices is important in considering specific regional } \\
\text { risks, and adaptation to climate change. }\end{array}$ \\
\hline $\begin{array}{l}\text { (Kiptot et al., } \\
\text { 2014) [34] }\end{array}$ & ajor contribution to food security depend on the level of \\
\hline $\begin{array}{l}\text { (Luiz } \\
2014\end{array}$ & $\begin{array}{l}\text { enhance carbon stock, basal area and the number of trees damaged } \\
\text { ested. }\end{array}$ \\
\hline (Coe et & $\begin{array}{l}\text { Agoforestry development should concern to the social, economic and ecological } \\
\text { context and how to create the need for local adaptation and appropriate } \\
\text { mechanisms for services, markets, and institutional contexts, as well as } \\
\text { technology. }\end{array}$ \\
\hline [44] & $\begin{array}{l}\text { Agroforestry contributes to climate chang } \\
\text { benefits. The obstacle to the adoption o } \\
\text { technological social change. }\end{array}$ \\
\hline [20] & ity is \\
\hline $\begin{array}{l}\text { (Kittur et a } \\
2013 b)\end{array}$ & s, and \\
\hline [26] & $\begin{array}{l}\text { inued conservation of the area as } \\
\text { ts. }\end{array}$ \\
\hline [40] & $\begin{array}{l}\text { Traditional agroforestry systems and reasons supporting farmers' choices turned } \\
\text { out to be the most diversified. The reasons that support farmers to conserve are } \\
\text { contribution to food, traditional medicine and farmers' perceptions of the } \\
\text { availability of natural vegetation. }\end{array}$ \\
\hline $\begin{array}{l}\text { (Magcale- } \\
\text { Macandog, } \\
\text { et.al., 2012). }\end{array}$ & $\begin{array}{l}\text { systems can provide high species diversity in ecosystem functions } \\
\text { ing high productivity }\end{array}$ \\
\hline [29] & $\begin{array}{l}\text { Appropriate adaptation programs include integrated increases in cropping area } \\
\text { and crop productivity, cropping intensity, and reduction of rice consumption } \\
\text { through food diversification. }\end{array}$ \\
\hline [32] & $\begin{array}{l}\text { A coherent policy for conflict management caused lack of convergence is } \\
\text { changing power dynamics. Dysfunctional government institutions encourage } \\
\text { stakeholders to seek alternative collaborations. Security forces are potential } \\
\text { partners in natural resource management }\end{array}$ \\
\hline [45] & $\begin{array}{l}\text { ty can be conserved at the middle income level. However, this } \\
\text { icient as the main source of income for garden owners. }\end{array}$ \\
\hline
\end{tabular}

This systematic review focusing on the fifteen years and the result shows that agroforestry become a driving factor of sustainable practiced in upland farming. Agroforestry within coffee farming become a requirement condition in achieving the resilience and mitigation mechanism toward risk in upland. More on implement 
agroforestry as the good agriculture practiced in uplan farming is prerequisite for sustainable production. The evidence of sustainable farming production that linked with resiliency and risk mitigation in upland still unadequated. Therefore, it is suggested that next empirical study in the future suppose consist of a few points. Firstly, conduct the research of resilience mechanism and risk mitigation in upland farming. Focus on how the sustainable production in upland has mechanism help to minimize the risk, especially in coffee farming as the largest smallholders plantation. Next, the efforts and support exploration need to concern on wisdom value from the local community regarding a sense of participatory and responsibility in a good sustainable land system. This systematic review has highlighted that agroforestry within coffee farming as good practiced in sustainable production in upland. It could minimize the threaten of environment sustainability and soil productivity.

\section{Conclusion}

This review article performed the fundamental steps of SLR and meta-analysis studies on environmental science and agricultural and biological science fields. The SLR protocol first step starts from planning review, citation screening, data extraction, review progress, the analysis result. The term search addressed to current study in sustainable production, especially in upland watersheds. Based on the systematic review step, this review has highlighted that agroforestry as a primary driving factor in directing the sustainable production in upland. Agroforestry within coffee farming could set as sustainable production system in upstream watersheds.

\section{References}

1. Kubankova M, Hajek M and Votavova A, Agric. Econ. (Zemědělská Ekon). 62, 10112 (2016)

2. Bernard F, Noordwijk M Van, Luedeling E, Villamor G B, Sileshi G W and Namirembe S, Environ. Sustain. 6, 155-61 (2014)

3. Eakin H, Tucker C M, Castellanos E, Juan R D and Helda F B, Adaptation in a multistressor environment: perceptions and responses to climatic and economic risks by coffee growers in Mesoamerica 123-39 (2014)

4. Unteawati B, Fiitriani and Zaini M, Kajian Sosial Ekonomi Masyarakat Pemanfaat Kawasan Hutan Lindung REG . 20 Kabupaten Pesawaran, in Prosiding Seminar Nasional Swasembada Pangan Politeknik Negeri Lampung, 25 April 2015, Lampung, pp 382-391(2015)

5. Fitriani F, Arifin B and Ismono H, J. Socioecon. Dev. 4, 120 (2021)

6. Fitriani, Arifin B, Zakaria W A and Ismono R H, Coffee agroforestry for sustainability of Upper Sekampung Watershed management Coffee agroforestry for sustainability of Upper Sekampung Watershed management International Conference on Biomass: Toward Sustainable Biomass Utilization for Industrial and Energy Applications (IOP Conference Series: Earth and Environmental Science) pp 1-13 (2018)

7. Fitriani, Arifin B, Abbas Zakaria W, Hanung Ismono R and Erry Prasmatiwi F, Int. J. Ecol. Dev. 35 (2020)

8. Fitriani, Arifin B, Zakaria W A and Ismono R H, J. Penelit. Pertan. Terap. 18, 65-74 (2018)

9. Anon Designing Agricultural Development Model for Lampung State using Social Accounting Matrix (SAM)

10. Mengist W, Soromessa T and Legese G, Method for conducting systematic literature 
review and meta-analysis for environmental science research MethodsX 7100777 (2020)

11. Kamioka H, Japanese Pharmacol. Ther. 47, 1177-1185 (2019).

12. Pullin A S and Stewart G B, Conserv. Biol. 20, 1647-1156 (2006).

13. Rosenstock T S, Lamanna C, Chesterman S, Bell P, Arslan A, Richards M, Rioux J, Akinleye A O, Champalle C, Cheng Z, Corner-dolloff C, Dohn J, English W, Eyrich A, Girvetz E H, Kerr A, Lizarazo M, Madalinska A, Mcfatridge S, Morris K S, Namoi N, Poultouchidou A, Ravina M, Richards M, Akinleye A O, Corner-dolloff C, English W and Eyrich A, The scientific basis of climate-smart agriculture A systematic review protocol GIAR Research Program Clim. Chang. Agric. Food Secur. ty (2015)

14. Secinaro S and Calandra D, Br. Food J.123, 1 (2020)

15. Shelby L B and Vaske J J, Understanding Meta-Analysis: A Review of the Methodological Literature Human and Social Dimensions of Global Environmental Change View project Coastal Management-Cebu, Philippines View project

16. Luo Z, Deng L and Yan C, Soil erosion under different plant cover types and its influencing factors in Napahai Catchment, (Shangri-La County, Yunnan Province , China 4509 (2015).

17. Coe R, Sinclair F and Barrios E, Environ. Sustain. 6, 73-77 (2014).

18. Valencia V, West P, Sterling E J, García-Barrios L and Naeem S, Ecosphere. 6, 1-17 (2015)

19. Binam J N, Place F and Kalinganire A, Effects of farmer managed natural regeneration on livelihoods in semi-arid West Africa (2015)

20. Dawson I K, Guariguata M R, Loo J, Weber J C, Lengkeek A, Bush D, Cornelius J and Guarino L, Biodivers Conserv. 22, 301-324 (2013)

21. Maryanto A, Murtilaksano K and Rachman M, J. Kehutan. Wallacea. 3, 2 85-96 (2014)

22. Lasco R D, Delfino R J P, Catacutan D C, Simelton E S and Wilson D M, Curr. Opin. Environ. Sustain. 6, 83-8 (2013)

23. Kittur B H and Bargali S S, J. Progress. Agric. 130 (2014)

24. Fauzi A and Anna Z, Ecosyst. Serv. 6 54-63 (2013)

25. Minang $P$ A, Duguma L A, Bernard F, Mertz $O$ and Noordwijk M Van, Curr. Opin. Environ. Sustain. 6, 78-82 (2014)

26. Reisland M A, Conservation in a Sacred Forest: An Integrated Approach to Assessing the Management of a Community-Based Conservation Site By Melissa Ann Reisland A dissertation submitted in partial fulfillment of the requirements for the degree of Doctor of Philosophy (Winconsin-Madison, 2013)

27. Purwanto S A, For. Trees, Livelihoods. 1-18 (2018)

28. Mbow C, Smith P, Skole D, Duguma L and Bustamante M, Curr. Opin. Environ. Sustain. 6, 8-14 (2014)

29. Syaukat Y, ISSAAS. 17, 40-51 (2011)

30. Lastiantoro C Y, Cahyono S A, Penelitian B, Kehutanan T, Das P, Yani J A and Box P O, J. Anal. Kebijak. Kehutan. 13, 203-12 (2016)

31. Luedeling E, Kindt R, Huth N I and Koenig K, Curr. Opin. Environ. Sustain. 6, 1-7 (2014)

32. Jaji H-A-R I, Managing Natural Resources And Conflict In Conflict-Affected Watersheds In The Philippines (State University of New York ,2011)

33. Ruhimat I S, Penelit. Sos. Ekon. Kehutan. 12, 99-110 (2015)

34. Kiptot E, Franzel S and Degrande A, Curr. Opin. Environ. Sustain. 6, 104-109 (2014)

35. Puspitojati T, Yamin Mile M, Fauziah E and Darusman D, Hutan Rakyat Sumbangsih Masyarakat Pedesaan untuk Hutan Tanaman ed Bahruni (Sleman, Yogyakarta: Penerbit Kanisius, 2014) 
36. Luiz A, Vianna M and Fearnside P M, Sustain. For. 9811 (2014)

37. Barrios E, Valencia V, Jonsson M, Brauman A, Hairiah K, Mortimer P E and Okubo S, Int. J. Biodivers. Sci. Ecosyst. Serv. Manag. 14, 1-16 (2018)

38. Takahashi R and Todo Y, Environ. Manage. 50, 396-404 (2012)

39. Rosin C and Dwiartama A, Resilience in Retrospective: Analysis of Response to Shocks and Stress in the New Zealand Kiwifruit and Sheep and Beef Sectors, (2012)

40. Assogbadjo A E, Kakaï R G, Vodouhê F G, Djagoun C A M S, Codjia J T C and Sinsin B, For. Policy Econ. 14, 41-49 (2012)

41. Chen H, Shivakoti G, Zhu T and Maddox D, Environ. Manage. 49, 219-228 (2012)

42. Magcale-Macandog D B, Visco R G and Delgado M E M, J. Sustain. Agric. 29, 97116 (2006)

43. Hidayat T, Pandjaitan N K, Dharmawan A H and Sitorus F, J. transdisiplin sosiologi, komunikasi, dan Ekol. Mns. 04, 1-16 (2010)

44. Jerneck A and Olsson L, J. Rural Stud. 32, 114-125 (2013)

45. Okubo S and Koji P, Agrofoestry Syst. 80, 17-31 (2010)

46. Santoso I, Ekonom. 13, 3 92-98 (2010)

47. Pender, John, Suyanto, John Kerr E K, Impacts of the Hutan Kamasyarakatan Social Forestry Program in the Sumberjaya Watershed, West Lampung District of Sumatra, Indonesia (2008)

48. Asah S T, Empirical Social-Ecological System Analysis: From Theoretical Framework to Latent Variable Structural Equation Model 1077-1090 (2008)

49. Tole L and Á C Á S, Environ. Manage. 45, 1312-1331 (2010)

50. Kittur B H and Bargali S S, J. Progress. Agric. 4, 91-94 (2013) 